\title{
Study on the Domestic Sewage Treatment by ABR-CW Method
}

\author{
Yang Zhijun \\ Beijing City University \\ Beijing, China \\ winneryzj@126.com
}

\author{
Zhang Xunhong Sui Zhili \\ Beijing City University \\ Beijing, China \\ zhangxuhong_w@126.com,sz1803@126.com
}

\begin{abstract}
Based on the status quo and requirements of domestic sewage treatment, the $A B R$ and widespread constructed wetland (CW) methods are used to treatment domestic sewage in rural area. By the $A B R$ and $C W$ treatment processes, the size and organic loading are designed on the basis of the sewage quality and quantity. The COD, TN, TP and $\mathrm{NH}_{4}{ }^{+}-\mathrm{N}$ are analysized by monitoring methods and its changed are analysized. The processing results are discussed and some conclusions are used to select to treat the domestic sewage in rural area.
\end{abstract}

Keywords- domestic sewage, ABR, CW, monitoring methods

\section{INTRODUCTION}

With the economic development and people's living standards improve, the resulting serious environmental pollution problems have become increasingly attentions. In the past, the environmental protection is focus on cities, while ignoring the larger area of the countryside. Thereby, the environmental problems are worsening in rural areas, especially the water pollution. Domestic sewage treatment in rural areas rise with rives and lakes aggravated pollution, but the sewage treatment engineering is less in rural areas, and many treatment technologies is only in demonstration research stage[1,2]. So, the low energy consumption, low running costs, low maintenance and management techniques are the main method to solve the sewage pollution problems in rural areas[3].

From the 1950s, the world in different countries and regions began to try to carry out wetland to purify sewage[4]. After half a century, the use of constructed wetland (CW) technology is gradually accepted and become more sophisticated[6]. Various countries had gradually established the sewage treatment system by $\mathrm{CW}$ method[7-8]. In treating the domestic sewage with a relatively small degree of pollution (CODcr $\left.<1000 \mathrm{mg} . \mathrm{L}^{-1}\right)$, which its removal is better, is a treatment technology using physical, chemical, biological of microbial and plant and its synergy action[9-10]. The thesis uses the $\mathrm{CW}$ and $\mathrm{ABR}$ methods to treat the domestic sewage of Beijing city.

\section{EXPERIMENTAL APPARATUS AND METHOD}

\section{A. Experimental apparatus}

The test water is the Beijing changping district domestic sewage. For personal change, the fluctuations of waste water quality change. So, anaerobic pretreatment unit (ABR) apparatus is used before the artificial constructed wetland (CW) to balance water quality and reduce impact loading. The parameters of $\mathrm{ABR}$ and $\mathrm{CW}$ apparatus are shown in table 1 and table 2 .

TABLE I. DESIGN PARAMETERS OF ABR

\begin{tabular}{|c|c|c|c|c|c|c|}
\hline \multirow{2}{*}{ Index } & $\begin{array}{c}\text { Size } \\
\text { L*D*H }\end{array}$ & Volume & Area & $\begin{array}{c}\text { Hydraulic } \\
\text { loading }\end{array}$ & HRT & \multirow{2}{*}{ Filling } \\
\cline { 2 - 6 } & $\mathrm{m}$ & $\mathrm{m}^{3}$ & $\mathrm{~m}^{2}$ & $\mathrm{~m}^{3} / \mathrm{m}^{2} \cdot \mathrm{d}$ & $\mathrm{d}$ & \\
\hline Value & $1.2 * 0.5 * 0.8$ & 0.45 & 0.6 & 0.25 & 1.28 & $\begin{array}{c}\text { Fiber } \\
\text { ball }\end{array}$ \\
\hline
\end{tabular}

TABLE II. DESIGN PARAMETERS OF CW

\begin{tabular}{|c|c|c|}
\hline Index & CW 1 & CW 2 \\
\hline Size $\left(\mathrm{L}^{*} \mathrm{D}^{*} \mathrm{H}, \mathrm{m}\right)$ & \multicolumn{2}{|c|}{$1.2^{*} 0.5^{*} 0.8$} \\
\hline Volume $\left(\mathrm{m}^{3}\right)$ & \multicolumn{2}{|c|}{0.45} \\
\hline Area $\left(\mathrm{m}^{2}\right)$ & $\begin{array}{c}\text { Up } \rightarrow \text { Down: zeolite, } \\
\text { bio-ceramic,anthracite. } \\
\text { Fffective height of each } \\
\text { floor is } 20 \mathrm{~cm}\end{array}$ & $\begin{array}{c}\text { Up } \rightarrow \text { Down: zeolite, bio- } \\
\text { ceramic, anthracite. } \\
\text { Effective height of each } \\
\text { floor is 20cm }\end{array}$ \\
\hline $\begin{array}{c}\text { Hyde \& number }) \\
\left(\mathrm{m}^{3} / \mathrm{m}^{2} \cdot \mathrm{d}\right)\end{array}$ & $\begin{array}{c}\text { 20ading } \\
\text { HRT }(\mathrm{d})\end{array}$ & \multicolumn{2}{|c|}{3.5} \\
\hline Flow direction & Upstream & Downstream \\
\hline
\end{tabular}

Anaerobic treatment is often used as a pre-treatment unit, which combined with aerobic treatment, can achieve good results. In this study, pretreatment technology is ABR method that jointly researched by Pro.Mccarty in 1982[13], with low energy consumption, long contact time between microorganism and domestic sewage, stable operation, good treatment effect, etc.

\section{B. Experimental methods}

The domestic sewage is taken in Beijng Changping district. The experiment is carried out during the day, and each sample is taken two parallel samples. "ABR+CW" method has two apparatuses, each unit takes three points and each sample number is 24 . Septic tank effluent through the pump into the ABR reactor, which has pollutant removal efficiency and can reduce fluctuations in water quality after preprocessed. The domestic sewage is taken into sump after treating by $\mathrm{ABR}$, and pumped into $\mathrm{CW}$ apparatus. The device runs $10 \mathrm{~h}$, from 8:00 to $18: 00$, and the total water inflow is $150 \mathrm{~L} \cdot \mathrm{d}^{-1}$. The indexes of domestic sewage, CODcr, $\mathrm{TN}, \mathrm{TP}, \mathrm{NH}_{4}{ }^{+}-\mathrm{N}$, are measured every $5 \mathrm{~d}$. The measurement method is dichromate method, alkaline potassium persulfate 
digestion-UV spectrophotometric method, ammonium molybdate spectrophotometric method, and Nessler's reagent spectrophotometry method, respectively to CODcr, TN, TP and $\mathrm{NH}_{4}{ }^{+} \mathrm{N}$.

\section{Raw Water quality}

The index of water quality is $100-500 \mathrm{mg} . \mathrm{L}^{-1}$ (CODcr), 10-50mg. $\mathrm{L}^{-1}$ (TN), 1-5mg. $\mathrm{L}^{-1}(\mathrm{TP}), \quad 4-16 \mathrm{mg} . \mathrm{L}^{-1}\left(\mathrm{NH}_{4}{ }^{+} \mathrm{N}\right)$, respectively. By measurement, the effluent index is 50230mg.L ${ }^{-1}$ (CODcr), 10-66mg.L $\mathrm{L}^{-1}$ (TN), 0.2-0.3mg.L ${ }^{-1}$ (TP), 1.3-17.5mg. $\mathrm{L}^{-1}\left(\mathrm{NH}_{4}{ }^{+}-\mathrm{N}\right)$ using ABR technology. So, the main effects of $\mathrm{ABR}$ are controlling water quality and reduce impact loading.

\section{RESULTS AND DISCUSSION}

A. The change Law of CODcr

The results of CODcr are shown in Figure 1 and Figure 2.

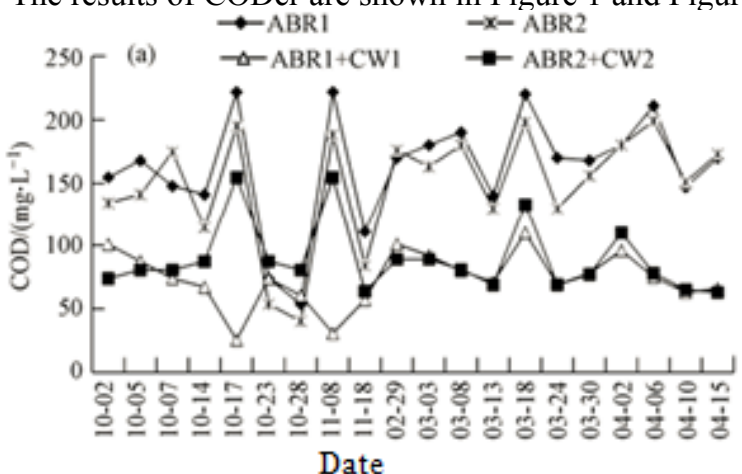

Figure 1. The value of CODcr before and after CW treatment

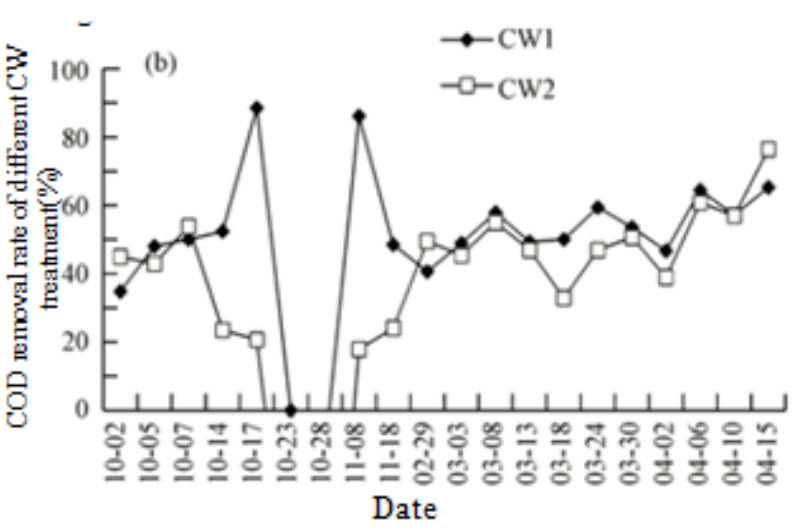

Figure 2. The CODcr removal rate of different $\mathrm{CW}$ treatment method

The Figure 1 and Figure 2 show that: the concentration of CODcr is $50-230 \mathrm{mg} . \mathrm{L}^{-1}$ and $20-150 \mathrm{mg} . \mathrm{L}^{-1}$, before CW treatment and after $\mathrm{CW}$ treatment, respectively. The mean value is $73.9 \mathrm{mg} . \mathrm{L}^{-1}$ after $\mathrm{CW}$ treatment, which reached the two standard of urban sewage treatment plant pollution discharge standard. From the Figure 1, "ABR1+CW1" and "ABR1+CW2" are two different ways of flow constructed wetland methods. CW1 is up flow, and CW2 is down flow.
Figure 1 shows that the water quality by " $\mathrm{ABR} 1+\mathrm{CW} 1$ " is better than "ABR1+CW2".

The reason is that the water impact loading is between in the pollution loading of wetland microbial-Matrix-Plants, which can adsorb and degrade. The impact loading is not reach saturation. The rate of discharge by CW1 method is $40 \%-90 \%$, the mean value is $60 \%$; The rate of discharge by CW2 method is $30 \%-80 \%$, the mean value is $50 \%$.

Figure 2 shows that the decontamination effect of up flow is better than down flow by constructed wetland method. The reason is that the water flow type can influence the hydraulic characteristics and water conduction, resulting different distribution layer of matrix aerobic and anaerobic, and different organic matter distribution. Compared to downstream, upstream is more evenly distributed of organic matter in CW1. After intercept and adsorption of underlying matrix, the underlying anaerobic or facultative microorganisms begin to initial degrade, and complex organic is compounded into simple organic by microorganisms. At the same time, as the water from the down to up, the simple organic is intercepted and absorbed by upper matrix, which upper aerobic microorganisms fully pay the role of degrading organic matter. By the together function of the matrix, anaerobic or facultative microorganisms, and aerobic microorganisms, the circulatory system of organic matter degradation forms from down to upper.

\section{B. The change Law of TN}

The results of TN are shown in Figure. 3 and Figure. 4

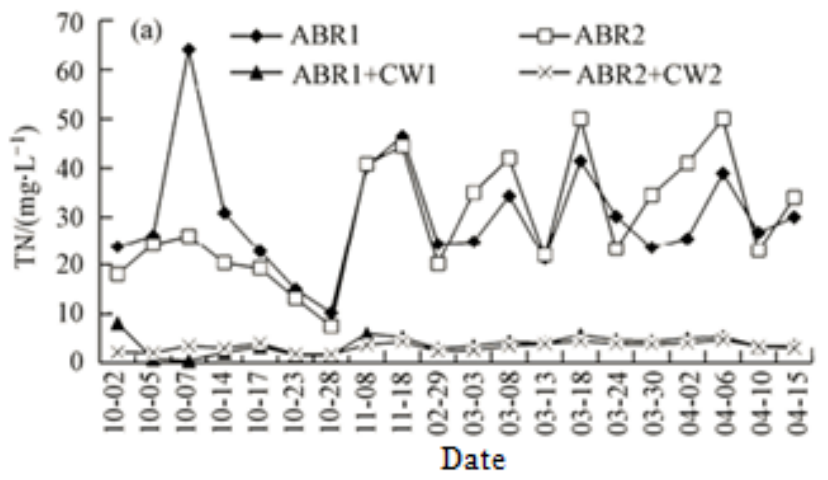

Figure 3. The value of $\mathrm{TN}$ before and after $\mathrm{CW}$ treatment

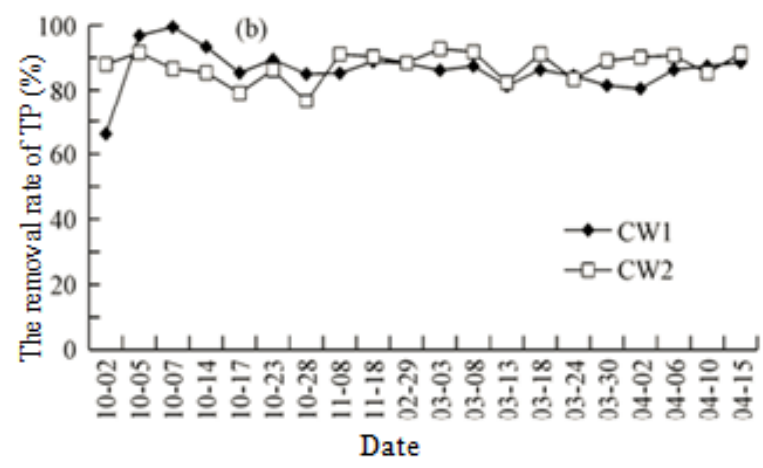

Figure 4. The TN removal rate of different $\mathrm{CW}$ treatment method 
The values of TP before and after constructed wetland treatment are shown in Figure 3 and Figure 4.

From the Figure 3, TN content of water before $\mathrm{CW}$ treatment has large fluctuations, the concentration of $\mathrm{TN}$ is 13-65 mg. $\mathrm{L}^{-1}$, the mean value is $40 \mathrm{mg} . \mathrm{L}^{-1}$. After $\mathrm{CW}$ treatment, the TN concentration of water is $0-9 \mathrm{mg} . \mathrm{L}^{-1}$, the mean value is $3.8 \mathrm{mg} . \mathrm{L}^{-1}$, which the $\mathrm{TN}$ value is stable. The total mean value is $4.0 \mathrm{mg} . \mathrm{L}^{-1}$. There is a similar concentration after $\mathrm{CW} 1$ and $\mathrm{CW} 2$ treatment methods, which reached to the A standard of pollutant emission standards of urban sewage treatment plant.

The Figure 4 shows that the removal rate of $\mathrm{TN}$ by "ABR+CW" treatment method is $65 \%-95 \%$, the mean is $85 \%$. The water quality is better after $\mathrm{CW}$ treatment. There are many influence factors of TN removal. The ABR1 and $\mathrm{CW}$ method forms a circulation system of TN, which the TN is in the form of ammonia, nitrate, nitrite nitrogen and organic nitrogen. This is a complex process of nitrogen conversion. Through the intercept and absorption functions of the zeolite, anthracite, bio-ceramic, et al, which haves a good removing effect, then through the jointing function of the nitrifying bacteria and denitrifying bacteria by constructed wetland treatment method, the water can reach a good effect of nitrogen removal.

\section{The change Law of TP}

The results of TP removal are shown in Figure 5 and Figure 6.

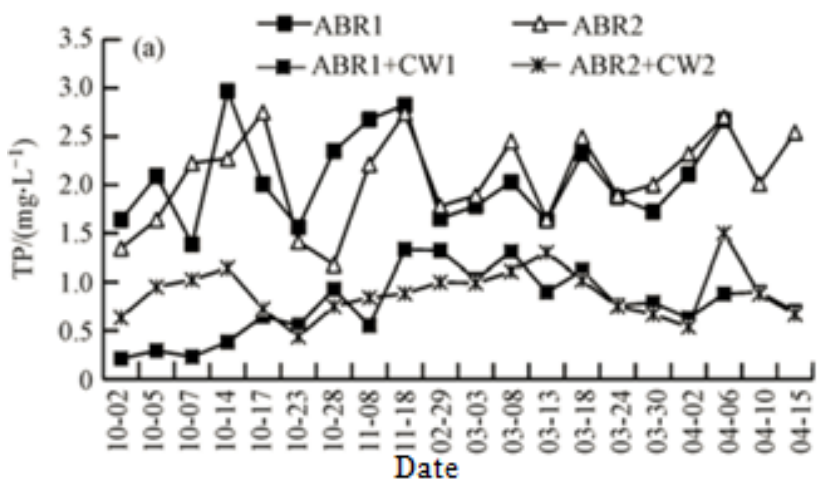

Figure 5. The value of TP before and after $\mathrm{CW}$ treatment

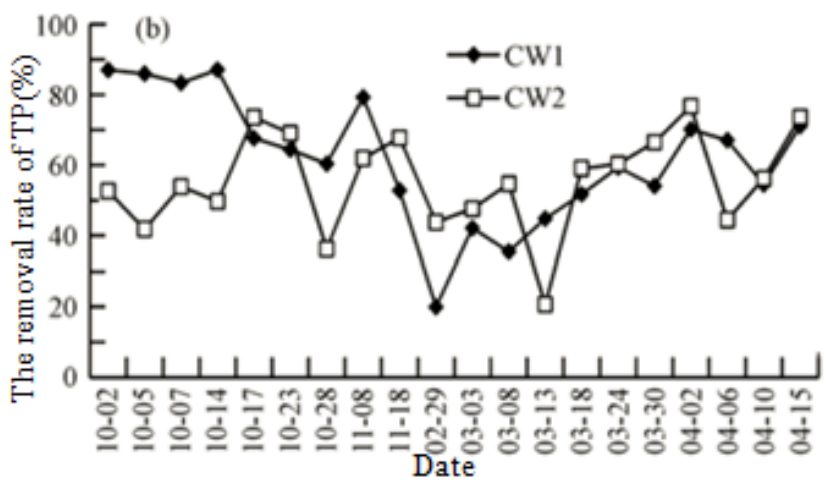

Figure 6. The removal rate of TP by different $\mathrm{CW}$ treatment method
The statistical results of TP concentrations by $\mathrm{CW}$ treatment method are shown in Figure 5 and Figure 6.

The Figure 5 shows that TP concentrations before and after CW treatment is $1.2-3.0 \mathrm{mg} . \mathrm{L}^{-1}$ and $0.2-1.4 \mathrm{mg} . \mathrm{L}^{-1}$, respectively, the mean concentration after treatment is $0.78 \mathrm{mg}^{-\mathrm{L}^{-1}}$.

The Figure 6 shows that the removal rate of TP is $20 \%$ $89 \%$ by CW1 treatment method, then the removal rate of TP is $20 \%-80 \%$ by CW2 method. So, the water quality by CW1 method is better than CW2. At the same time, the Figure 6 shows that seasonal changes are not the important factors to " $\mathrm{ABR}+\mathrm{CW}$ " treatment effect.

D. The change Law of $\mathrm{NH}_{4}{ }^{+}-\mathrm{N}$

The results of $\mathrm{NH}_{4}{ }^{+}-\mathrm{N}$ removal are shown in Figure 7 and Figure 8.

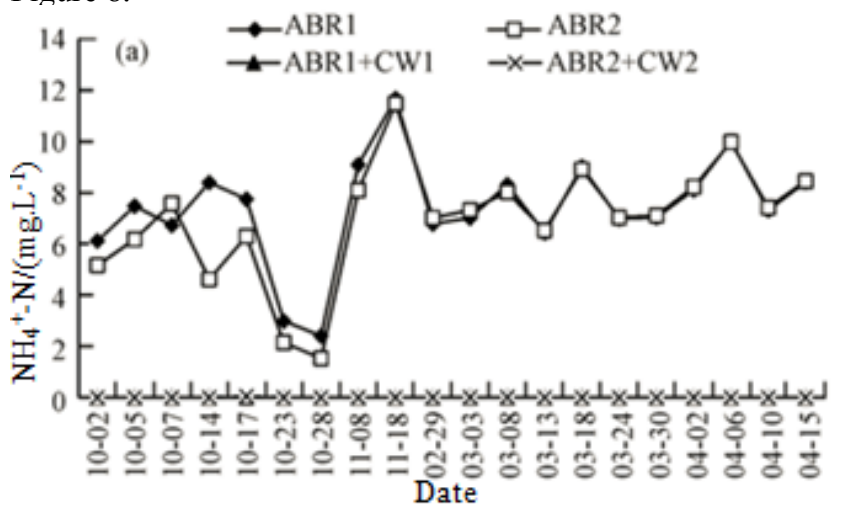

Figure 7. The value of $\mathrm{NH}_{4}{ }^{+}-\mathrm{N}$ before and after $\mathrm{CW}$ treatment

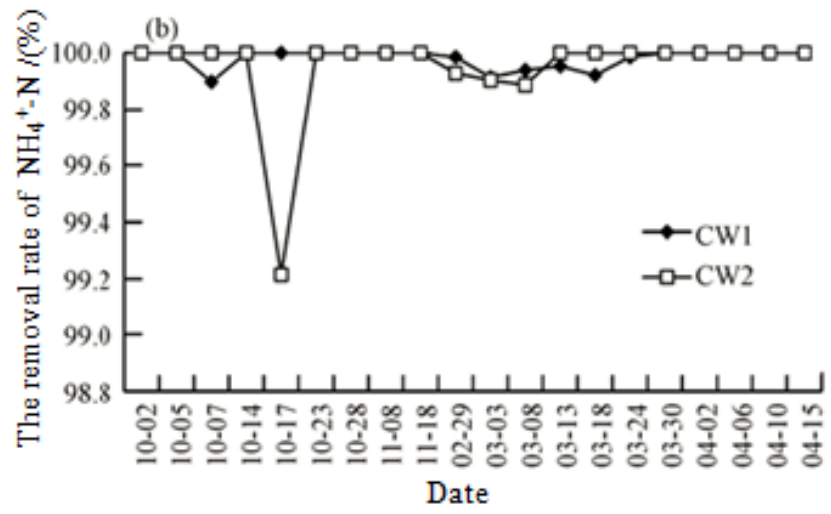

Figure 8. The removal rate of $\mathrm{NH}_{4}{ }^{+}-\mathrm{N}$ by different $\mathrm{CW}$ treatment method

The statistical results of $\mathrm{NH}_{4}^{+}-\mathrm{N}$ concentration and removal rate are shown in Figure 7 and Figure 8.

The Figure 7 shows that $\mathrm{NH}_{4}{ }^{+}-\mathrm{N}$ concentration has large fluctuations between $1.3 \mathrm{mg} . \mathrm{L}^{-1}$ and $11.8 \mathrm{mg} . \mathrm{L}^{-1}$ before constructed wetland treatment method. The concentration is almost to 0 after constructed wetland treatment method. The removal rate is reached to $99 \%$, and the treatment effect is very well shown in Figure 8. From Figure 8, we can also see that CW1 and CW2 have the same effect, in addition to CW2 has a special value. The reason is that there is adequate oxygen content within in the matrix of constructed wetland method, which makes ensure the smooth progress of 
nitrification and make the $\mathrm{N}$-transfer circulation system can be orderly.

\section{SUMMARY}

On the basis of the study on domestic sewage by ABR1 and $\mathrm{CW}$ treatment methods, some conclusions are shown that:

(1) The water quality is better by "ABR $+C W$ " method than ABR method. CODcr, TN,TP and $\mathrm{NH}_{4}{ }^{+}-\mathrm{N}$ can reach the two standard, one standard(A), one standard(B) and one standard(A) of pollutant discharge standard of urban sewage treatment, respectively.

(2) Form the removal rate index, the removal rate of CODcr, TN, TP and $\mathrm{NH}_{4}{ }^{+}-\mathrm{N}$ is $50 \%-60 \%, 85 \%, 80-90 \%$, and $99 \%$, respectively. So, the removal rate of domestic sewage is very well.

(3) The treatment effect is less impacted as temperature varies, but is positively correlated with fluctuations in raw water quality. It is because of the pollution loading has not reached to saturation sake.

\section{ACKNOWLEDGMENT}

The paper is supported by promotion project of development of private education-educational reform-"new major construction-water supply and drainage engineering" of beijing city university.

\section{REFERENCES}

[1] Cao Qun, She Jiarong, Treatment technologies for rural domestic sewage. Envionmental science and management, vol. 34(3), 2009, pp. $118-121$
[2] Brix, Hans, Arias, Carlos A, Danish guidelines for small-scale constructed wetland systems for onsite treatment of domestic sewage. Water sicence and technology, vol.51(9),2005, pp.1-9.

[3] Huang Peng, Guo Yaoguang, Lou Xiaoyi, et al, Survey of rural domestic sewage treatment systems of Songjiang district in Shanghai, China. Environment sicence and material engineering, vol.573574,2012,pp.511-515.

[4] Hench, Keith R, Bissionnette, Gary K, Sexstone, Alan J, et al, Fate of physical, chemical and microbial contaminants in domestic wastewater following treatment by small constructed wetlands. Water research, vol.37(4),2003, pp.921-927.

[5] Gao Da-wen, Hu Qi, Bio-contact oxidation and greenhouse-structured wetland system for rural sewage recycling in cold regions: A fullscale study. Ecological engineering, vol.49,2012,pp.249-253

[6] Liu Xiaolu, Niu Hongbin, Yan Hai, et al, Research and application of high-efficiency eco-engineering rural sewage treatment system.Nongye gongcheng xuebao/transactions of the Chinese society of agricultural engineering, vol.29(9),2013,pp.184-191.

[7] Philippi Luiz S, Da Costa, Rejane H.R, et al, Domestic effluent treatment through integrated system of septic tank and root zone. Water science and technolog, vol.40(3),1999,pp.125-131.

[8] Mantovi, Paolo, Marmiroli, Marta, Maestri, Elena, et al, application of a horizontal subsurface flow constructed wetland on treatment of dairy parlor wastewater. Bioresource technology, vol.88(2),2003,pp.85-94.

[9] Zhang Weiyi, Yao Lirong, Wang Liyan, et al, Effects of rural domestic sewage treatment in Taihu Lake Valley by wetland of pant floating island. Nongye Gongcheng Xuebao/Transactions of the Chinese scoiety of agricultural engineering,vol.26(8),2010,pp.279284

[10] Zhang Yuefeng, Liu Shentan, Xie Xiangfeng, et al, Nitrogen removal of rural domestic sewage in subsurface constructed wetlands. Jiangsu Daxue xuebao(Ziran kexue ban)/ Journal of Jiangsu university (Natural science edition), vol.32(4),2011, pp.487-491. 